\title{
1．東日本大震災への国土地理院の対応
}

\section{Countermeasures of the Geospatial Information Authority of Japan against the Great East Japan Earthquake}

\author{
政春 尋志* ·永山 透* \\ Hiroshi MASAHARU and Toru NAGAYAMA
}

\begin{abstract}
概要：東日本大震災への国土地理院の対応について，地殼変動監視，空中写真等による災害状況把握とその分析，関係 機関への地理情報の提供の活動, 復興に向けての活動等の概要を報告する。

Abstract : We report the countermeasure activities of the Geospatial Information Authority of Japan against the Great East Japan Earthquake in terms of monitoring of crustal deformation, grasping disasters by means of aerial photographs, photo interpretation, geographic analysis, providing related agencies with geospatial information, and others.
\end{abstract}

\section{1.はじめに}

2011年 3 月11日に発生した東北地方太平洋沖地震は 未曾有の大災害をもたらした。国土地理院は，災害状 況の把握と国・地方自治体等の関係機関への情報提供 に全力で取り組んできた。本稿ではその概要を報告す る。今回の地震では広範囲に大きな地殻変動が起こっ たことから，地理空間情報の位置の基準の扱いにも課 題を投げかけているので，地震に伴う地款変動につい て最初に解説する。

\section{GEONETで観測された地殼変動と測量成果の改} 定

国土地理院が全国に 1200 点あまり設置している電子 基準点網 GEONET によって地震に伴う大きな地殼 変動が広域にわたって観測された(図 1 )。電子基準点 「牡鹿」で東南東に $5.3 \mathrm{~m}$ の水平変動, $1.2 \mathrm{~m}$ の沈降が観 測された。これらはこれまでに GEONET で観測され た最大の水平変動量と沈降量である。東北地方の太平 洋沿岸の広い範囲で地盤の沈降が観測され, 現在も浸 水被害をもたらしている。不動と見なされる点を基準 とした相対的な変動量で各点の地款変動を表示してい るが，地殼変動は西日本を含む広域に及んでおり，地

*国土地理院

「写真測量とリモートセンシング」VOL. 50, NO. 4, 2011

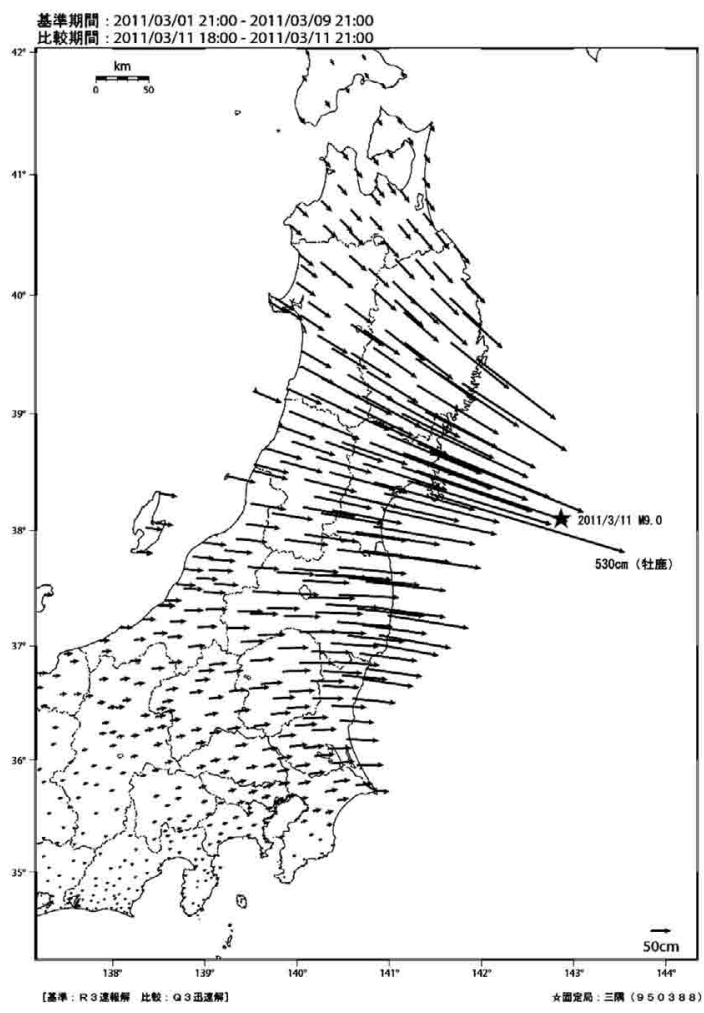

図 1 東北地方太平洋沖地震による水平地殻変動（出典： 国土地理院 http://www.gsi.go.jp/common/ 000059672.pdf) 
殻変動困の表示に用いた島根県の「三隅」もわずかな がら動いているため, 地殼変動の解析には長崎県の「福 江」を固定点としている。

地款変動デー夕は地震像を明らかにする上で重要な 情報であり，己れの解析に基づいて，最初に 2 枚の長 方形で近似した断層モデル，次いでプレート境界面上 での滑り分布モデルを推定し公表した(困 2 )。この滑 り分布モデルから導かれた東北地方太平洋岸の沈降量 の分布は, 気象庁が地盤の沈降による大潮の時期の浸 水・冠水への注意を促した報道発表（気象庁，2011） にも引用されるなど防災に役立てられた。地款変動の 解析の結果, この地震の震源域におけるプレート沈み 込みによるひずみの350～700年分に相当する量が今回 の地震と余効滑り（地震に伴う大きなプレート境界で の滑りの後に滑りが継続している現象）で解消された と推定され，プレート境界がふだんは強く固着してひ ずみを蓄積し巨大地震で解放されていることがわかっ た (Ozawa et al., 2011)。

余効変動（余効滑りと余震による地殼変動を含む） は 7 月 12 日現在までで, 最大水平変位量が $65 \mathrm{~cm}$, 断層

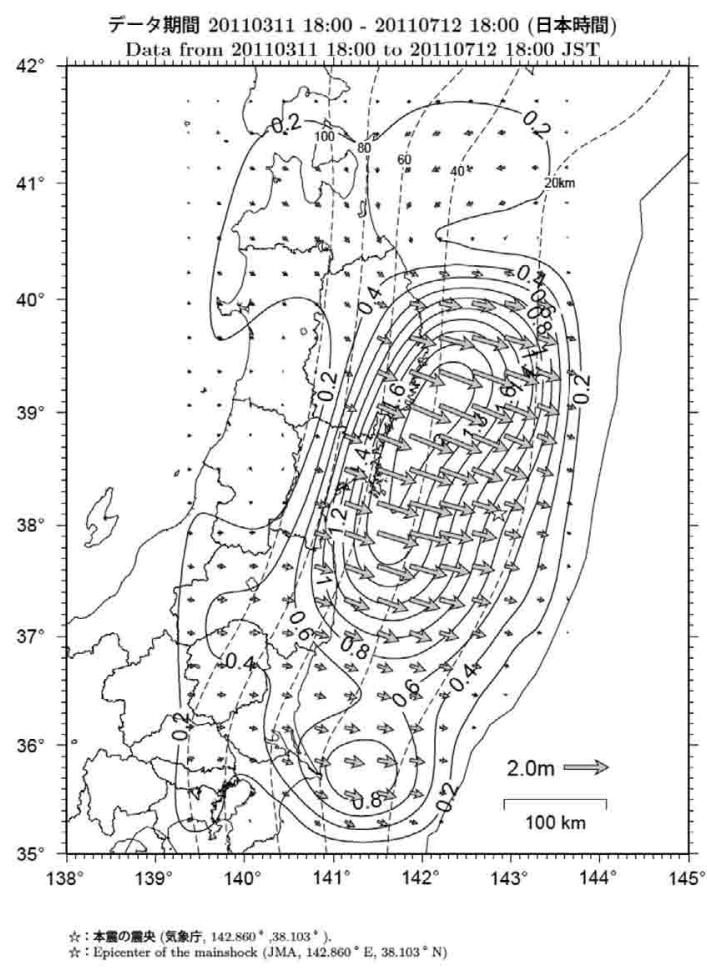

図 3 地震後のプレート境界面上のすべり分布モデル（出 典：国土地理院, 2011)

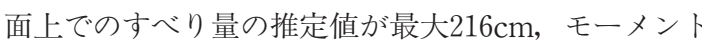

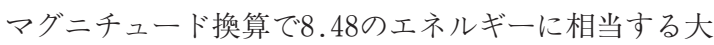
きなものとなっている。余効滑りが起こっている領域 は地震時の滑り領域よりも陸側のプレート境界の深い 側によっている(図3)。

地震に伴う広域の大きな地殼変動のために，まず， 3 月14日に青森県から長野県に至る16都県で基準点成 果の公表を停止した。測量の基準点は復旧・復興に欠 かせないものなので, 主要三角点の改測を行って10月 下旬を目標に新しい測量成果を得るとともに，改測を 行わない三角点については補正パラメーターにより新 しい成果を算出し公表する予定である。日本経緯度原 点の位置も変動していると推定されることから，6月 に変動後の経緯度を正確に決めるための測量が行われ た。電子基準点については余効変動がある程度小さく なるのを待って 5 月31日に438点の電子基準点につい ての成果の公表と記者発表を行った。この際, 今回の 地震の地款変動が今まで例にないほど広域に及んだこ とから, 西日本の測量成果と整合するため電子基準点 の成果改定を行う地域を，3月14日の成果公表停止地 域に富山県・石川県・福井県・岐阜県を加えた地域と した。

高さの基準である水準点については, 県単位ではな く水準路線単位であるが成果の公表を停止し, 改測を 行っている。これについても10月末までに新しい成果 を公表予定である。なお, 被災地沿岸部の復旧・復興 のための各種工事の設計等に役立てるため, 同地域の 一部の水準点においては「標高速報值」として 8 月上 旬までには関係機関へ提供する予定である。

このように, 広域で大きな地款変動が起こったため, 公共測量成果も改定が必要となっている。公共測量成 果を効率よく改定できるよう, 国土地理院では 10 月末 に補正パラメーターを提供すべく，準備をすすめてい る。

\section{3. 空中写真撮影による災害状況の把握と画像情報の 提供}

地震災害は突発的であり，大規模な災害の場合その 被害状況を把握するために一刻も早い空中写真撮影が 必要である。国土地理院は航空測量機「くにかぜIII」 を保有して災害時の撮影に備えているが, 折悪しく 3 月末まで定期点検中であった。今回の災害は範囲が非 常に広域であるため, 複数機による撮影が必要でも 
あった。災害時の緊急撮影のために，国土地理院と財 日本測量調查技術協会は協定を交わしており，これに 基づいて協会加盟の対応可能な協力会社を調查してい ただき， 6 社（14日に 1 社追加して計 7 社）と契約し て翌日12日から範囲を分担して撮影を開始した。協定 の内容や(財)日本測量調查技術協会の協力活動について は本特集の谷岡（2011）を参照されたい。12日と13日 の二日間で青森県から福島県北部に至る太平洋沿岸の かなりの部分の撮影ができたが，その後は天候に恵ま れず，19日に宮城県の一部が撮影できただけで，協定 撮影による撮影は終了した。なお，当初は栗駒山地区 の撮影を実施したが，積雪もあり中止した。4 月以降 は 1 日と 5 日に「くにかぜIII」により，青森〜宮城の 未撮影地域や，雲で地表の状況が撮影できなかった地 域の再撮影を行い，青森県から福島県北部までの津波 被災地域（福島第一原子力発電所の事故による飛行制 限区域を除く）の撮影が完了した（図 4)。

撮影された写真は一刻も早く政府や被災地域の関係 機関に提供するよう要請があった。このため, 画像情 報のデー夕処理，ハードコピーの作成などをできるだ

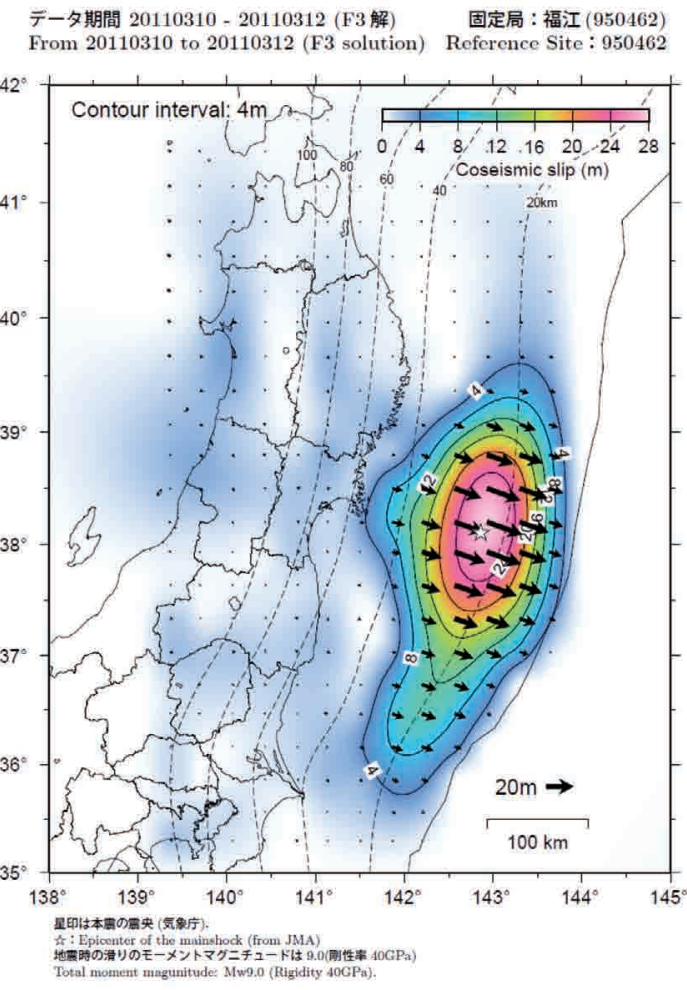

図2 東北地方太平洋沖地震のプレート境界面上のすべり 分布モデル（出典：国土地理院，2011）

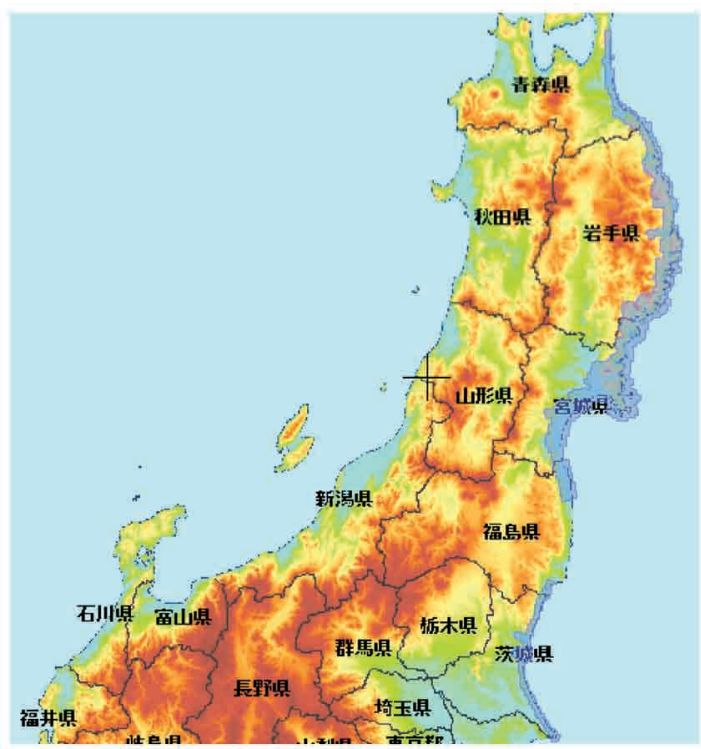

図 4 空中写真撮影範囲 (2011年 3 月 12 日〜 4 月 5 日) 太平 洋岸の青色箇所（出典：国土地理院 http://portal. cyberjapan.jp/denshi/index3_tohoku.html)

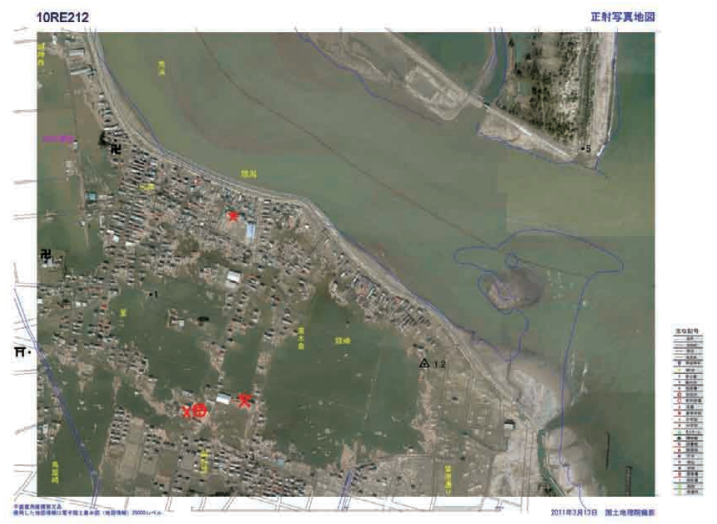

図 5 正射写真地図の例（正射写真地図仙台地区 図郭10 RE212）（出典：国土地理院 http://saigai.gsi.go. jp/h23taiheiyo-zort/map/index.html)

け迅速に行うよう努め, 撮影した写真は翌日（一部に ついては翌々日）にはウェブに公開した。さらに，撮 影時の GPS/IMU データと既存の DEM を用いて作 成した簡易オルソ画像と，これに地図情報を重ね合わ せた正射写真地図（図 5 ）の作成を行い，ウェブに公 開した。このようなオルソ画像作成と画像のモザイク 合成が迅速にできるようになったのは，GPS/IMU データにより写真の標定要素が直接に計測できるよう になったこととデジタル写真測量システムの発展によ るところが大きいことはいうまでもない。 


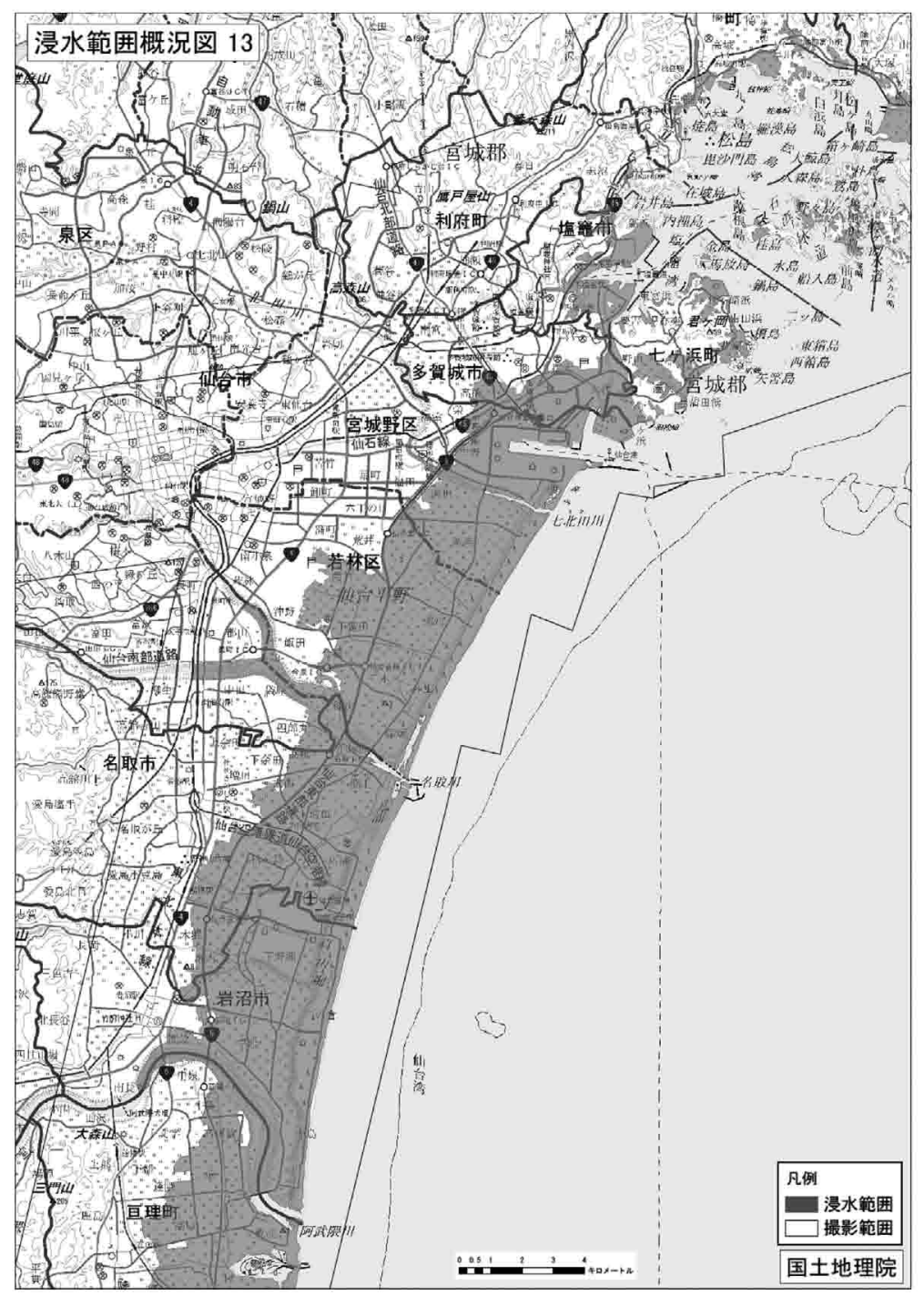

図 6 10万分 1 浸水範囲概況図（出典：国土地理院 http://www.gsi.go.jp/common/000060133.pdf）

また，一部の激甚な被災地域について，被災前後の 写真を比較する資料を作成・公開した。さらに，5 月 18日からは，被災地域の斜写真を撮影し，順次公開 しているところである。これら被災後の空中写真は, 今回の被害の寸さまじさを物語っている。

\section{4. 津波浸水範囲の判読}

被災地の空中写真から様々な情報が読み取れる。今 回の地震では最も大きな被害をもたらしたのが津波で あり，被害状況の把握のために津波で浸水した範囲を 明らかにすることが求められた。写真判読の熟練者が チームを組んで大量の写真の判読に当たり, 津波の浸
水範囲を 2 万 5 千分 1 地形図に描くとともにその面積 を集計した(図 6 )。この結果，青森県から千葉県に至 る浸水面積の総計は $561 \mathrm{~km}^{2}$ と推計された。さらに，こ の浸水範囲と，国土数值情報の土地利用データの重ね 合わせ分析を行って主な土地利用種別ごとの浸水面積 を推計した。

\section{5. 関係機関への地理情報の提供}

災害発生時には状況把握のために緊急に地図が必要 になる。国土地理院では地震発生当日に被災地域の 2 万 5 千分 1 地形図等の紙地図を, 要請に応じて首相官 邸はじめ関係機関に配布した。その後, 空中写真画像 
や浸水範囲の判読結果など，被災状況に関する地理情 報を, 自衛隊, 県, 地方整備局等に提供するとともに, これら機関の協力を得つつ順次市町村にも配布した。 これら地理情報は，国民がネットワークでも状況を把 握できるようインターネットで公開したが，被災地域 の関係機関の多くは停電等により, 高速ネットワーク へのアクセスやデジタルデータの処理ができる状況で はなく出力図やハードコピーのニーズが圧倒的であっ た。その後, 被災地域でも徐々に電力等が復旧し, 要 請のあった機関に対しては, デジタルデータ一式を ハードディスク等の物理的なメディアに格納して配布 した。

政府の現地焱害対策本部が宮城県に設置された際に は, 国土地理院緊急災害対策派遣隊 (TEC-FORCE) として常時 2 名の職員を派遣し, 情報ニーズの把握, 提供等の活動を行った。大判プリンターを持ち込んで, 地図や空中写真の出力を各機関の要請に応えて行っ た。

地理情報の提供に関しては, 地図上に各種のデータ を重ね合わせて表示することができる電子国土 Web システムを利用した，交通規制情報，デジタル標高地 形図, シームレスな正射画像デー夕の公開も行った。

これらの地理情報は, 現地における救難活動, 道路・ 鉄道・空港等基幹交通インフラの被災状況の把握, 災 害查定, 農地での津波被害調査, 建物罹災証明発行な ど，様々な災害対応業務に活用されている。これら情 報は国土地理院ホームページに開設した「平成23年 （2011年）東日本大震災に関する情報提供」のページ (http://www.gsi.go.jp/BOUSAI/h23_tohoku.html) に扔いて公開している。

\section{6. 観測施設の被災状況}

常時地殼変動を監視している電子基準点で, 地震に 伴って東北地方太平洋岸の多くの点で停電と通信断が 発生し, 当日の時点では数十点のデータが取れない状 況になった。電子基準点はバッテリーを内蔵し，72時 間または24時間の停電があってもデー夕取得は継続で きるようになっている。また, 通信回線も専用回線と 携帯電話回線の二重化をしている。

今回のような大地震に際して重要な地殼変動のデー 夕が失われてはならないので, 現地に出張し, 一部の 点には太陽電池を取り付け，それまでに取得されてい たデータを回収した。また，太陽電池と衛星携帯電話
を備えて自立的に地款変動観測ができるREGMOS (GPS 火山変動りモート観測装置) 1 機を,「M 牡鹿」 点に取り付けてデータ取得が継続できるようにした。

幸い，比較的早く電力や通信が回復した点が多く， 地殼変動デー夕の取得には大きな問題はなかった。津 波で被災し, 復旧が必要な点は 3 点だった。

相馬験潮場は津波により完全に倒壊した。これは再 建する予定であるが，それまでの経過措置として，無 事だった県の験潮施設をお借りして国土地理院の験潮 儀を設置し験潮デー夕を取り始めている。

\section{7. 復興に向けて}

災害からの復旧・復興のために, 最新の地理情報が 必要である。国土地理院では, すでに述べたように三 角点の測量, 水準測量を広範囲に実施し，10月末まで に成果をまとめて公表することとしている。

また, 被災状況を含む現状を正確に表し, 復興計画 策定に役立てられることを目的とした縮尺 $1: 2,500$ の災害復興計画基図を東北地方太平洋岸の被災地域に ついて作成中である。自治体による計画策定作業が急 がれているので, この地図データも, 暫定データとし て, 都市計画区域については 8 月に各自治体に提供す る予定である。

さらに，地殼変動によって引き起こされた地盤の沈 降が沿岸地域で大きな問題になっている。このため正 確な標高データのニーズが高い。国土地理院では, 東

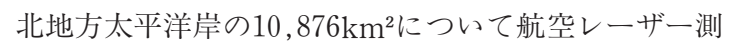
量による精密な標高データの整備にも取り組んでい る。このデー夕は, 納品後順次関係機関等へ提供する 予定である。

\section{8.おわりに}

東日本大震災は広域の大災害であり, 国を挙げて復 興に当たることが求められている。国土地理院は地元 自治体や関係機関のニーズにできる限り応えて, 地理 情報整備の点から復旧・復興に貢献することとしてい る。今後, 早期の復興に向けた多様なニーズに応えら れるよう, 高品質の地理情報の迅速な整備・提供, 地 理空間情報の一層の活用, 空間情報技術のさらなる発 展が必要とされているところである。

\section{参考文献}

気象庁，2011.「平成23年 (2011年) 東北地方太平洋沖 
地震」による地盤の沈下に伴う大潮の時期における 浸水や冠水の抢それの高まりについて (平成 23 年 3 月17日報道発表資料), http://www.jma.go.jp/jma/ press/1103/17b/ooshio.pdf

国土地理院, 2011. 東北地方の地凯変動, 地震予知連 絡会会報, 87巻, 印刷中.

谷岡誠一, 2011. 東北地方太平洋沖地震発生時の緊急 撮影について, 写真測量とリモートセンシング, Vol. 50, No. 4, pp.185-191.
永山 透，2011。東日本大震災に対する国土地理院の 取り組み，測量，61 (6), pp. 9-13.

Ozawa, S., T. Nishimura, H. Suito, T. Kobayashi, M. Tobita and T. Imakiire, 2011. Coseismic and postseismic slip of the 2011 magnitude -9 Tohoku -Oki earthquake, Nature, doi : 10.1038/nature 10227. (日本語による概要が http://www.gsi.go.jp/ cais/topic110620-index.htmlにある) 